\title{
Assessing the achievements of the Millennium Development Goals in Southern Africa
}

\author{
Eric O. Udjoa \& Pinky Lalthapersad-Pillayb \\ aBureau of Market Research, University of South Africa \\ PO Box 392 UNISA 0003, Pretoria, South Africa \\ Tel: 012- 429 3326; Fax: 012-429 6225 \\ Email: udjoe@unisa.ac.za \\ bDepartment of Economics, University of South Africa \\ PO Box 392 UNISA 0003, Pretoria, South Africa \\ Email: lalthp@unisa.ac.za
}

\begin{abstract}
The Millennium Development Goals (MDGs) were put forward in early 2000 and the targets are to be reached in 2015. They are an inclusive set of well- defined goals that primarily seek to put development at the forefront of national agendas by persuading governments to commit resources to address socio-economic backlogs in their respective countries. Many reports have been produced on progress with The Millennium Development Goals but certain methodologies do not accurately reflect individual country's progress. Governments need adequate information about their country's performance. In this article, the performance of Southern African countries is analyzed separately. Time series data sourced from the United Nations data base were used to estimate parameters. The results suggest that of the six MDG goals examined, none of the Southern African countries is poised to achieve all six goals. At best, Botswana and Swaziland could achieve three of the goals.
\end{abstract}

Keywords: Millennium Development Goals, Southern Africa, poverty, education, child and maternal mortality, HIV/AIDS

\section{Résumé}

Les objectifs du Millénaire pour le développement (OMD) ont été soumises au début de 2000 et les objectifs sont à atteindre en 2015. Ils constituent un ensemble inclusif de puits - objectifs définis qui visent principalement à mettre le développement au premier rang des agendas nationaux en persuadant les gouvernements à consacrer des ressources pour résoudre des retards socio-économiques dans leurs pays respectifs. De nombreux rapports ont été produits les progrès dans la réalisation des $O M D$, mais certaines méthodes ne reflètent pas exactement les progrès accomplis par chaque pays. Les gouvernements doivent une information adéquate sur les performances de leur pays. Dans cet article, les performances des pays d'Afrique australe sont analysé séparément. Données de séries chronologiques provenance de la base de données des Nations Unies ont servi à estimer les paramètres. Les résultats suggèrent que les six objectifs OMD examinés, aucun de l'Afrique du Sud pays est sur le point d'atteindre tous les six objectifs. Au mieux, Botswana et Swaziland pourraient atteindre trois des objectifs.

Mots clés: Millennium Development Goals, Afrique australe, la pauvreté, l'éducation, mortalité infantile et maternelle, le $\mathrm{VIH} /$ sida 


\section{Introduction}

The Millennium Development Goals (MDGs) were put forward in early 2000 and the targets are to be reached in 2015. The MDGs are an inclusive set of well-defined goals that primarily seek to put development at the forefront of national agendas by persuading governments to commit resources to address socio-economic backlogs in their respective countries. The Goals cover a range of socioeconomic dimensions, including poverty reduction, education, gender equality, HIV/AIDS, infant and maternal mortality and environmental issues. The MDG exercise showed that the international community, together with governments, businesses and civil society can be rallied to bolster human development and to impel the fight against poverty and disease.

\section{Literature Review}

\section{International Initiatives in Development Goals}

The regular compilation and publication of some objective quantitative and qualitative criteria (indicators) are necessary to measure performance, monitor progress and inform policies pertaining to socioeconomic development. A number of initiatives have been undertaken internationally in this regard. Williams and Smith (2000) cited in Udjo et al (2000a, $2000 \mathrm{~b}$ ), provide a comprehensive review of such initiatives, which include the Minimum National Social Data Set (MNSDS) of the United Nations (UN); the Basic Social Services for All (BSSA) of the UN; the Organisation for Economic Co-operation and Development (OECD); Development Assistant Committee (DAC)/World Bank/UN's working core set of indicators of Development Progress (IDP); United Nations Development Assistance Framework's Common Country Assessment indicators (CCA); International Monetary Fund's (IMF) General Data Dissemination System (GDDS) and Special Data Dissemination Standard (SDDS); and the World Bank's Comprehensive Development Framework (CDF), Highly Indebted Poor Countries (HIPC) and Poverty Reduction Strategy Plans (PRSP).

In a series of UN global conferences, concern was voiced about major development issues pertaining to education (Jomtien, Thailand, 1992), children (New York, 1990), the environment and development (Rio de Janeiro, 1992), population and development (Cairo, 1994), social development (Copenhagen, 1995) and women (Beijing, 1995). The outcome was that in 1996, development ministers of the Organisation for Economic Corporation and Development (OECD) countries formulated a strategy for development based on seven international goals.
These priorities were to be achieved before 2015 in order to improve the quality of life in developing countries. The goals which were in the fields of economic well-being, social development and environmental protection included reducing by half of the proportion of people living in extreme poverty by 2015; achieving universal primary education by 2015; eliminating gender disparity in primary and secondary education by 2015; reducing infant and child mortality by two-thirds of the 1990 levels by 2015; reducing maternal mortality by three-fourths the 1990 level by 2015; improving access to reproductive health services through the primary health-care system for all individuals of appropriate ages, including safe and family planning methods by 20I5; and reversing trends of losses in environmental resources by 2015 (OECD, 1998, 2000).

To assess progress with regard to the goals, a set of 21 core indicators (Indicators of Development Progress, (IDP)) was defined by OECD Development Assistance Committee (DAC), the World Bank and the UN. In addition to monitoring progress in various fields of development, the core indicators provided a yardstick for assessing the effectiveness of strategies in the said fields (OECD, 1998). The indicators that have been internationally developed or proposed tend to overlap. The initiatives emphasised cross-country comparisons through the application of uniform methods and definitions used in the computation of the indicators. However, aggregate measures such as the IDP and other international indicators do not adequately reflect the diversity of a country's population (Udjo, 2000a, 2000b). The OECD's international development targets were especially important in the context of the Millennium Declaration and with the inclusion of a few more targets; they became the MDGs. Thus the emphasis in recent times on the Millennium Development Goals (MDGs) to some extent is a reenactment of development goals ratified in previous international initiatives and conventions (Waage et al., 2010).

\section{Overview of the Millennium Development Goals}

The Millennium Development Goals emanated from the United Nations Millennium Declaration in 2000 and constituted the most crucial political pact governing international development (UNDP 2003). The Millennium Declaration underscored six values considered to be fundamental to international relations and seven objectives were identified to operationalize these values (Waage et al. 20I0). The Millennium Declaration which was adopted by 189 states comprised of 8 Goals, 18 time-bound targets and 48 quantitative indicators (UN 2003). There has been mixed reaction to the MDGS. In some quarters it has been lauded for among other things, being a 
massive global effort focusing on poverty; lobbying development policy; encouraging the flow of aid and investment; generating a development paradigm in low-income countries and advocating effective monitoring and evaluation tools given that the goals were simple, measurable and tangible (Waage et al, 2010; Moss \& Clemens 2005; Sumner \& Tiwari 2009; $\mathrm{CIGI} \& \mathrm{KDI} 2012$ ). On the other hand the MDGs have been chastised for among other things, espousing development standpoints of the 1980s and 1990s; being flawed conceptually and practically (Hailu \& Tsukada: 20II, Waag et al.: 2010); being technically confounding; being too sector-specific with targets too tautly defined; packaging of goals, targets and indicators are seen to hinder accomplishment; reinforcing inequity given the achievement of a specific minimum standard; articulating development priorities in a manner that are not functional to countries and of excluding certain development priorities like human trafficking (Waage et al, 20I0; Moss \& Clemens 2005; CSIS 2010).

\section{Views about Progress in the MDGs}

There have been numerous reports tracking progress towards the achievement of the Goals. Overall progress towards the MDGs has been varied as evinced that least progress has been made in Africa and south Asia (UN 2010; Hogan et al. 2010). The UN as early as 2008 warned that "on current trends, no African country is likely to achieve all of the Goals" (UN, 2008). The United Nations review of the MDGs in 2010 found that although the whole MDG process appeared to be on track, most countries had made only minimal advancement with regards to set targets. Nevertheless, the conclusion reached was that the final outcome is likely to be aligned to the initial expectations on which the Goals were premised (UN 20I0).

\section{Research problem}

As already noted, a number of reports, including country-specific reports have been produced on progress regarding the MDGS (see Williams \& Smith 2000; UNICEF 2008; World Bank and IMF 20I0; United Nations 2010). Certain aspects of the methodology used to assess progress tend to treat all countries as if they were of the same level of socioeconomic development. For example, UNICEF's 2008 State of the World's Children report (cited in Hailu \& Tsukada 20II) measured changes in underfive mortality across countries by calculating the countries' annual average rate of reduction (see Hailu \& Tsukada 20II). It is inappropriate to apply an average situation for all countries to individual countries in the context of the MDG especially if the range of the values of the indicator is wide. For example, while under-five mortality in Egypt was estimated as 25 per thousand live births during the period 2010-2015, it was 180 per thousand live births in the Democratic Republic of the Congo during the same period (UN 20I2).

Using a 'average performance for all countries' is cumbersome as averages do not accurately reflect individual country's progress and countries run the risk of being misled about the true nature of their performance. Governments need to be adequately informed about their specific country's performance in achieving targets so suitable interventions can be put in place to improve performance if necessary.

Another point to note in the MDG reports for Southern African countries is that there is no indication of the likely year certain targets which were stated as not achievable, are likely to be achieved given present developments in the countries. The Botswana 2010 MDG report (The Government of Botswana, 2010) expressed optimism in meeting the target for certain goals but also noted that some of the targets are not achievable. The Swaziland report (Government of Swaziland, 20I2) noted that achieving some of the targets in Swaziland is a challenge and while the country is on track in some of the targets, acceleration of programmes is required in goals I, 4 and 5). Similarly should read: Similarly, in the Namibian and Lesotho reports (Government of the Republic of Namibia, 2013; Government of the Kingdom of Lesotho, 2014), there is an indication of slow progress in achieving certain goals. In the South Africa report (Republic of South Africa, 2013), there is admission that the country is unlikely to achieve some of the goals. What is lacking from the reports is estimating the year the MDG target is likely to be reached in the case where it is not likely to be reached by 2015 . If this information were available and the year is too far, it would further galvanise governments into further action in accelerating progress in those dimensions of the MDG. In this article therefore, we analyze the performance of Southern African countries separately in selected MDG goals with regard to set targets and provide trends beyond 2015 .

\section{Objectives}

The overall aim of this article is to assess progress made by Southern African countries (including Botswana, Lesotho, Namibia, South Africa and Swaziland) in achieving certain Millennium Development targets. Specifically, the article provides: (I) estimates of 2015 targets at country level with regard to eradicating extreme poverty; achieving universal primary education; achieving gender equality; reducing child mortality; improving maternal health as well combating HIV/AIDS; (2) 
Analysis of country level progress in meeting the MDG targets for the selected MDG goals with a view to answering the following questions: which Southern African countries are poised to reach the selected MDG targets? If not, by which year are these Southern African countries likely to reach the specific MDG targets?

\section{Data and limitations}

The data for this article were time series indicators from the United Nations (20I2) data base. However, these data sources also had glaring limitations. Firstly, the available data points for each indicator spanning the period 1990 to 2010 varied from country to country. Secondly, each country's data though compiled by the country's statistical offices originated from different sources such as the census, income and expenditure surveys, labour force survey, demographic and health surveys, HIV prevalence surveys as well as data from modeling and global monitoring The quality of data from different sources even within a country might vary let alone, across countries. Although the data are provided with a cautionary note that they have been adjusted by the responsible specialized agencies to ensure international comparability, the methodologies of such adjustments are not given and therefore cannot be appraised.

Thirdly, is the issue of definition? Although the MDG indicators have standardized definitions, definitions vary from country to country, for example, the definition of the literacy rate of 15-24 year olds. These definitional limitations undermine the comparability of figures between and even within countries and in view of this, the figures presented in this article should be interpreted as indicative as it is not purpose of this article to present exact figures but to examine general trends. It should be noted that the data were those available at the time of the study and since then some of the figures may have been updated for some of the selected countries. For the reasons noted above, we avoid comparisons between countries and treat each country separately. Reasons for the individual performance of each country also fall outside the scope of the article as it entail major policy review.

\section{Methods}

The analysis in this article involved estimating the following: MDG target; percentage annual reduction still required to achieve the MDG target; time series beta coefficient and probable year that countries will achieve their MDG target. The methods of estimation of each of these parameters are outlined below.
MDG 2015 target

Outside those indicators that require $100 \%$ coverage, the baseline figure used in computing the 2015 target for a particular indicator was the figure for 1990 or available figure closest to 1990 for each country. Thus for each country, a two-thirds reduction in child hood mortality between 1990 and 2015 for example, was computed as: the 1990 value (or closest figure) - (1990 value * 0.6667$)$.

Percentage annual reduction still required to achieve the MDG target.

The percentage annual reduction, still required to achieve the MDG target for a particular goal, in a specific country was estimated using the following equation:

$R \%^{i, c}=O \%^{i, c} /\left(T Y \%^{i, c}-Y C \%^{i, c}\right)$

Where $R \%^{i, c}$ is the percentage annual reduction still required to achieve MDG target for a specified indicator $i$, in a specified country c; $O \%$ is the overall percentage reduction still required to achieve the MDG target for the specified indicator for the specified country; $T Y$ is the terminal year of the MDG target which is 2015 and $Y C$ is the year of the most current estimate. The overall percentage reduction still required to achieve MDG target on the on the right hand of equation I, was estimated as:

$O \%^{i, c}=\left[\left(T Y T^{i, c}-C Y E^{i, c}\right) / C Y E^{i, c}\right] * 100$ (2)

Where $O \%^{i, c}$ is the overall percentage reduction still required to achieve MDG target for a specified indicator $i$, in a specified country, $c$; TYT is the estimated target for the specified indicator for the specified country at the terminal year; CYE is the most current estimate for the specified indicator for the specified country. These computations assume a linear trend in the indicators except for HIV prevalence.

\section{Time series beta coefficient}

The time series beta coefficient in this article is a measure of the overall change in a specified indicator between the base year and current year (i.e. change in the indicator per unit of time period). Estimating the beta coefficient for a specified indicator in each country involved the following steps. Firstly, the level of indicator was plotted against the year for which the level of indicator was estimated. This produced a time series scatter plot of the level of the indicator against the time period. Secondly, a regression line was fitted to the scatter plot using a linear regression equation defining a straight line:

$y=a+b x$ 
Where $y$ is the specified indicator, $a$ is the intercept, and $b$ is the slope of the regression line or beta coefficient and $x$ is the time period. The computation of $a$ and $b$ was based on the least squares method. Each scatter plot was scrutinized with the purpose of excluding outliers before fitting the regression line. With the exception of trends in under-five mortality and HIV prevalence, the scatter plots for the indicators in each country in general were linear. Regarding trend in under-five mortality, in the absence of "mortality upheavals" if a country is experiencing improvement in overall all mortality in the general population, under-five mortality should show a linear trend and where mortality has stagnated, trend in under-five mortality should be flat. The second to last sentence should read: Departure form this pattern such as inverted "U-shaped" curve is indicative of "mortality upheaval "during the periods of inversion and may be due to several factors such as epidemics, socio-economic factors, access to health services. In the present study, the overall trend in under-five mortality during the period under consideration was non-linear. The regression line was therefore based on the most recent performance in under-five mortality which corresponded to the period 2006 onwards. These points were linear. No attempt was made in this article to do any curve fitting on the HIV prevalence rates. The course of HIV prevalence resembles a gamma curve (S-shaped curve) in populations with a generalized epidemic and fitting a gamna curve to the data usually requires demographic and epidemiological data for each country. These were not available to the authors.

\section{Probable year to achieve MDG target}

In cases, where the estimates indicated that a country would not be able to achieve the MDG target for the said indicator, the probable year to achieve the MDG target for that indicator was estimated using the regression equation specified in equation (3) above to extrapolate the time series data in the scatter plot assuming a linear trend. It has been suggested that a linear equation may not be appropriate in projecting future performance in MDG targets (Hailu \& Tsukada 20II). We considered a linear approach adequate in this article for the following reasons. (I) The scatter plot of the time series data in general showed a linear trend with the exception of under-five mortality and HIV prevalence. (2) There is no curve fitting method that can predict future performance with certainty. All mathematical methods of curve fitting break down the farther away into the future the curve fitting is extrapolated because the assumptions underlying the methods are not tenable when the time period for the extrapolations exceed say five years. (3) More elaborate methods of curve fitting often require more data. Hence, the probable year to achieve a specified MDG target provided in this article should be interpreted as indicative rather than exact estimates and were based on the assumption that observed trends in the data (excluding outliers) are likely to continue.

\section{Results}

Goal I pertains to eradicating extreme poverty and hunger and one target seeks to halve between 1990 and 20I5, the proportion of people whose income is less than I\$ a day. The indicator is the proportion of the population below I\$ a day. Due to paucity of data in respect of this indicator for Botswana and Namibia, the analysis was confined to Lesotho, South Africa and Swaziland.

Current estimates suggest that as of 200I, about $63 \%$ of the population in Swaziland, $43 \%$ in Lesotho in 2003 and $17 \%$ in South Africa had an income below I\$ a day. There was a linear trend in the performance for the indicator between 1995 and 2005 in Swaziland, Lesotho and South Africa (graph not shown) suggesting a decline in the proportions of people whose income was less than I\$ a day in these countries. 
Table I: Summary Estimates of Progress: Percentage of the population below a I\$ a day

\begin{tabular}{|l|l|l|l|l|l|}
\hline & Botswana & Lesotho & Namibia & $\begin{array}{l}\text { South } \\
\text { Africa }\end{array}$ & Swaziland \\
\hline 2015 target (\%) & 15.6 & 28.2 & 24.6 & 12.2 & 39.3 \\
\hline $\begin{array}{l}\text { Annual reduction still } \\
\text { required to achieve } \\
\text { target (\%) }\end{array}$ & 0.1 & -2.3 & 0.1 & -2.2 & -3.3 \\
\hline Beta coefficient & - & -0.909 & - & -0.384 & -2.617 \\
\hline $\begin{array}{l}\text { Overall trend in \% of } \\
\text { population with income } \\
\text { less than I\$ a day }\end{array}$ & - & Improvement & - & Improvement & Improvement \\
\hline $\begin{array}{l}\text { Estimated \% } \\
\text { population with income } \\
\text { less than I\$ a day in } \\
20 \text { I5 }\end{array}$ & - & 32 & - & 15.9 & 26.1 \\
\hline $\begin{array}{l}\text { Comment } \\
\text { Probable year to achieve }\end{array}$ & - & $\begin{array}{l}\text { Unlikely to } \\
\text { achieve } \\
\text { target }\end{array}$ & - & $\begin{array}{l}\text { Unlikely to } \\
\text { achieve } \\
\text { target }\end{array}$ & $\begin{array}{l}\text { Likely } \\
\text { achieve } \\
\text { target }\end{array}$ \\
\hline SDG target & 2019 & - & 2025 & - \\
\hline
\end{tabular}

Source: Authors' estimates.

Table I provides a summary of the analysis for this indicator. The estimates derived from the base year figures indicate that the percentage of population whose income is less than $1 \$$ a day is $28 \%$ in Lesotho, 12\% in South Africa and 39\% in Swaziland. On the basis of current performance, Lesotho would still need to reduce poverty by $2.3 \%$ per annum, South Africa by $2.2 \%$ per annum and Swaziland by $3.3 \%$ per annum to achieve the 2015 target. The time series data suggest that although each of the three countries have reduced the percentage of the population whose income is less $\mathrm{t} \mid \$$ a day, Lesotho and South Africa are unlikely to achieve the MDG target and if past and current trends continued, Lesotho would probably achieve the target in 2019 while South Africa may do so in 2025.

Goal 2 deals with universal primary education and one target aims to ensure that by 2015 children everywhere, boys and girls alike, will be able to complete a full course of primary schooling. One of the indicators in assessing progress in achieving universal primary education is the net enrolment ratio in primary school which is the percentage of children of primary school age who are enrolled in primary education in a given year. This ratio measures the extent to which persons of school age are enrolled in school. Disaggregating this by sex provides additional insight as to whether there is disparity between the sexes in attainment of universal primary education and also provides insight into MDG Goal 3 (Promote gender equality and empower women).

The estimates based on the available data indicate that the male net enrolment ratio is currently about $88 \%$ in Botswana, $76 \%$ in Lesotho, $92 \%$ in Namibia,
$90 \%$ in South Africa and $84 \%$ in Swaziland. These figures are less than the target of $100 \%$ in respect of universal primary education for boys. Estimates for girls indicated a similar pattern. However, the net enrolment in primary school is generally higher for girls than for boys which suggest that proportionately, more girls of official primary school age are enrolled in primary schools compared with boys of similar age.

Progress in achieving universal primary education per country is summarized in Table 2. The trends suggest that Botswana would still require an annual increase in net enrolment ratio of $2 \%$ for boys and girls between 2007 and 2015 to achieve the MDG target of $100 \%$. Lesotho requires an annual increase of about $7 \%$ for boys and $10 \%$ for girls in net enrolment ratio between 2009 and 2015 to achieve the MDG target. Overall, the beta coefficients suggest that there has been improvement in net enrolment in primary school for boys and girls in Botswana, and Swaziland. In Namibia, the net enrolment in primary school remains stagnant for boys and girls. There has been a reduction in net enrolment in primary in Lesotho and South Africa with girls experiencing a larger reduction than boys in both countries. In view of these trends, none of the Southern African countries is likely to achieve the MDG target in achieving universal primary education. However, if recent trends continue, Botswana may achieve the MDG target by 2027 and Swaziland by 2021. Lesotho and South Africa would need to reverse the reduction in net enrolment while Namibia would need to improve its current stagnant state if they were to make progress in achieving universal primary education. 
Table 2: Summary Estimates of Progress in Achieving Universal Primary Education in Southern Africa: Boys

\begin{tabular}{|c|c|c|c|c|c|}
\hline Boys & Botswana & Lesotho & Namibia & South Africa & Swaziland \\
\hline 2015 target (\%) & 100 & 100 & 100 & 100 & 100 \\
\hline $\begin{array}{l}\text { Annual increase } \\
\text { still required to } \\
\text { achieve target (\%) }\end{array}$ & 2.0 & 6.7 & 2.3 & 2.1 & 2.7 \\
\hline Beta coefficient & 0.792 & -0.502 & 0.010 & -0.484 & 1.467 \\
\hline $\begin{array}{l}\text { Overall trend in } \\
\text { Net } \\
\text { ratio }\end{array}$ & Improvement & Decline & Stagnant & Decline & Improvement \\
\hline $\begin{array}{l}\text { Estimated Net } \\
\text { Enrolment ratio in } \\
2015\end{array}$ & 93.4 & 68.1 & 88.3 & 87.1 & 91.3 \\
\hline Comment & $\begin{array}{l}\text { Unlikely to } \\
\text { achieve target }\end{array}$ & $\begin{array}{l}\text { Unlikely to } \\
\text { achieve target }\end{array}$ & $\begin{array}{l}\text { Unlikely to } \\
\text { achieve } \\
\text { target }\end{array}$ & $\begin{array}{l}\text { Unlikely to } \\
\text { achieve target }\end{array}$ & $\begin{array}{l}\text { Unlikely to } \\
\text { achieve target }\end{array}$ \\
\hline $\begin{array}{lr}\begin{array}{l}\text { Probable } \\
\text { achieve }\end{array} & \text { Mear to } \\
\text { target } & \\
\end{array}$ & 2023 & - & - & - & 2021 \\
\hline Girls & Botswana & Lesotho & Namibia & South Africa & Swaziland \\
\hline 2015 target (\%) & 100 & 100 & 100 & 100 & 100 \\
\hline $\begin{array}{l}\text { Annual increase } \\
\text { still required to } \\
\text { achieve target (\%) }\end{array}$ & 2.0 & 104 & 1.5 & 2.0 & 3.3 \\
\hline Beta coefficient & 0.552 & -0.843 & -0.092 & -0.506 & 1.408 \\
\hline $\begin{array}{ll}\text { Overall } & \text { trend in } \\
\text { net } & \text { Enrolment } \\
\text { ratio } & \\
\end{array}$ & Improvement & Decline & Stagnant & Decline & Improvement \\
\hline $\begin{array}{l}\text { Estimated Net } \\
\text { Enrolment ratio in } \\
2015\end{array}$ & 93.1 & 69.2 & 93.0 & 88.4 & 91.6 \\
\hline Comment & $\begin{array}{l}\text { Unlikely to } \\
\text { achieve target }\end{array}$ & $\begin{array}{l}\text { Unlikely to } \\
\text { achieve target }\end{array}$ & $\begin{array}{l}\text { Unlikely to } \\
\text { achieve } \\
\text { target }\end{array}$ & $\begin{array}{l}\text { Unlikely to } \\
\text { achieve target }\end{array}$ & $\begin{array}{l}\text { Unlikely to } \\
\text { achieve target }\end{array}$ \\
\hline $\begin{array}{lr}\text { Probable } & \text { year to } \\
\text { achieve } & \text { MDG } \\
\text { target } & \end{array}$ & 2027 & - & - & - & 2021 \\
\hline
\end{tabular}

Source: Authors' estimates.

Goal 3 deals with gender equality and the target is to eliminate gender disparity in primary and secondary education, preferably by 2005 , and in all levels of education no later than 2015. The indicator for assessing progress in this goal is the ratio of girls to boys in primary, secondary and tertiary education. Absolute numbers of girls and boys are not appropriate for computing this ratio as the result would be biased since sex ratio in the school going age (or in most ages) is not $I$ in human populations. In view of this, the ratio of net female enrolment to net male enrolment was used and the analysis was confined to primary education. A value of $I$ in this ratio indicates gender equality in primary education, a ratio greater than $I$ indicates gender inequality in primary education in favour of girls while a ratio less than $I$ indicates gender inequality in primary education in favour of boys.

The ratios were over 100 during the period 2000 2010 (except in Botswana in 2004) indicating gender inequality in primary education in favour of girls. This is consistent with the pattern observed in the previous section where it was noted that proportionately, more girls of official primary school age were enrolled in primary schools compared with boys of similar age.

The summary estimates shown in Table 3 indicate that overall, there has been improvement in reducing gender inequality in primary school education in four southern African countries except South Africa 
where gender inequality in primary education has stagnated. Botswana, Lesotho and Swaziland are likely to achieve the MDG target pertaining to gender equality in primary education. If current trends continue, Namibia may achieve gender equality in primary education in 2017 and South Africa in 2028.

Table 3: Summary Estimates of Progress in Achieving gender equality in Primary Education in Southern Africa

\begin{tabular}{|c|c|c|c|c|c|}
\hline & Botswana & Lesotho & Namibia & South Africa & Swaziland \\
\hline 2015 target (\%) & 100 & 100 & 100 & 100 & 100 \\
\hline $\begin{array}{lr}\text { Annual } & \\
\text { reduction } & \text { still } \\
\text { required } & \text { to } \\
\text { achieve } & \text { target } \\
(\%) & \\
\end{array}$ & -0.258 & -0.269 & -0.905 & -0.830 & -0.239 \\
\hline Beta coefficient & -0.264 & -0.608 & -0.578 & -0.077 & -0.112 \\
\hline $\begin{array}{l}\text { Overall trend in } \\
\text { female to male } \\
\text { net enrolment } \\
\text { ratio }\end{array}$ & Improvement & Improvement & Improvement & Stagnant & Improvement \\
\hline $\begin{array}{l}\text { Estimated ratio } \\
\text { in } 2015\end{array}$ & 100 & 100 & 101 & 101 & 100 \\
\hline Comment & $\begin{array}{l}\text { Likely to } \\
\text { achieve target }\end{array}$ & $\begin{array}{l}\text { Likely to } \\
\text { achieve } \\
\text { target }\end{array}$ & $\begin{array}{l}\text { Likely to } \\
\text { achieve target }\end{array}$ & $\begin{array}{l}\text { Unlikely to achieve } \\
\text { target }\end{array}$ & $\begin{array}{l}\text { Likely to } \\
\text { achieve target }\end{array}$ \\
\hline $\begin{array}{l}\text { Probable year to } \\
\text { achieve MDG } \\
\text { target }\end{array}$ & - & - & 2017 & 2028 & - \\
\hline
\end{tabular}

Source: Authors' estimates.

Goal 4 deals with under-five mortality. The trends in the estimates in the UN database indicate a steep increase in under-five mortality rates in the mid1990s to 2000 for all countries, except Namibia where the increase was less steep. In Lesotho (which has the highest under-five mortality), it increased from about 89 per thousand live births in 1990 to about 127 per thousand live births in 2000. In South Africa (which had the lowest under-five mortality in the 1990s), it increased from about 60 per thousand live births in 1990 to about 78 per thousand live births in 2010. The UN figures suggest that underfive mortality rates began to decline in Southern African countries after 2000. The period of sharp increases in under-five mortality rates coincides somewhat with the period of sharp increases in HIV prevalence in the Southern Africa countries but it would be incorrect to solely attribute the increase in under-five mortality rates to increases in HIV prevalence.

The beta coefficients in Table 4 indicate that there has been a reduction in under-five mortality rates in recent years in the Southern Africa countries with Lesotho achieving an overall reduction of about $9 \%$ between 2006 and 2010 and Botswana achieving an overall reduction of about $2 \%$ during the same period. If current trends continue, aside from Namibia, it is unlikely that other southern African countries would achieve their MDG target. Swaziland may achieve its target (of 32 per thousand live births) in 2016 while Lesotho may achieve its target (29 per thousand live births) in 2017. 
Table 4: Summary Estimates of Progress in reducing Under-five Mortality in Southern Africa

\begin{tabular}{|l|l|l|l|l|l|}
\hline & Botswana & Lesotho & Namibia & South Africa & Swaziland \\
\hline $\begin{array}{l}\text { 20I5 target (per } \\
\text { 1000 live births) }\end{array}$ & 19.5 & 29.4 & 24.1 & 19.8 & 31.7 \\
\hline $\begin{array}{l}\text { Annual reduction } \\
\text { still required to } \\
\text { achieve target (\%) }\end{array}$ & -11.9 & -13.1 & -8.0 & -13.1 & -11.9 \\
\hline Beta coefficient & -1.7 & -8.6 & -3.4 & -4.7 & -7.7 \\
\hline $\begin{array}{l}\text { Overall trend in } \\
\text { recent under-five } \\
\text { mortality rates }\end{array}$ & Improvement & Improvement & Improvement & Improvement & Improvement \\
\hline $\begin{array}{l}\text { Estimated under- } \\
\text { five mortality rate } \\
\text { in 20I5 }\end{array}$ & 39 & $4 I$ & 23 & 33 & 37 \\
\hline $\begin{array}{l}\text { Comment to } \\
\text { achieve target }\end{array}$ & $\begin{array}{l}\text { Unlikely } \\
\text { achieve target } \\
\text { achieve target }\end{array}$ & $\begin{array}{l}\text { Unlikely to } \\
\text { achieve target }\end{array}$ & $\begin{array}{l}\text { Unlikely } \\
\text { achieve target }\end{array}$ \\
\hline $\begin{array}{l}\text { Probable year to } \\
\text { achieve } \\
\text { target MDG }\end{array}$ & \begin{tabular}{l}
2027 \\
\hline
\end{tabular} & - & 2018 & 2016 \\
\hline
\end{tabular}

Source: Authors' estimates.

Goal 5 deals with maternal health. The target is a three-quarters reduction in the maternal mortality ratio, the indicator being the maternal mortality ratio. Trends in maternal mortality ratios in the UN figures suggest that the maternal mortality ratio (MMR) (the number of maternal deaths per 100, 000 live births) has been rising in Southern African countries since the mid-1990s but current levels appear to suggest that the rates may have declined in recent years in Botswana, Lesotho and Swaziland. The period of the sharp increase in maternal mortality ratios countries coincides with the period of sharp increases in HIV prevalence in the countries but it would be incorrect to attribute the increase solely to HIV prevalence. For example, Udjo and Lalthapersad-Pillay (2014) estimated that in 2007 only about $11 \%$ of the differences in maternal mortality ratio in the provinces in South Africa were explained by differences in HIV prevalence at provincial level.

Table 5: Summary Estimates of Progress in improving Maternal Mortality in Southern Africa

\begin{tabular}{|c|c|c|c|c|c|}
\hline & Botswana & Lesotho & Namibia & South Africa & Swaziland \\
\hline $\begin{array}{lll}2015 & \text { target } & \text { (MMR } \\
\text { per } 100,000 & \text { live } \\
\text { births) } & & \\
\end{array}$ & 21 & 93 & 45 & 58 & 65 \\
\hline $\begin{array}{l}\text { Annual reduction } \\
\text { still required to } \\
\text { achieve target (\%) }\end{array}$ & -12.7 & -11.8 & -10.7 & -12.3 & -12.1 \\
\hline Beta coefficient & 8.6 & 12.2 & 1.7 & 12.0 & 11.9 \\
\hline $\begin{array}{l}\text { Overall trend in } \\
\text { recent } \text { Maternal } \\
\text { Mortality Ratio } \\
\end{array}$ & Upward & Upward & Upward & Upward & Upward \\
\hline $\begin{array}{l}\text { Estimated Maternal } \\
\text { Mortality Ratios in } \\
2015\end{array}$ & 332 & 645 & 224 & 530 & 518 \\
\hline Comment & $\begin{array}{l}\text { Unlikely to } \\
\text { achieve target }\end{array}$ & $\begin{array}{l}\text { Unlikely to } \\
\text { achieve } \\
\text { target }\end{array}$ & $\begin{array}{l}\text { Unlikely to } \\
\text { achieve } \\
\text { target }\end{array}$ & $\begin{array}{l}\text { Unlikely to } \\
\text { achieve target }\end{array}$ & $\begin{array}{l}\text { Unlikely to } \\
\text { achieve target }\end{array}$ \\
\hline $\begin{array}{l}\text { Probable year to } \\
\text { achieve MDG target }\end{array}$ & - & - & - & - & - \\
\hline
\end{tabular}

Source: Authors' estimates. 
The beta coefficients in Table 5 indicate that during the period 1990 to 2008, the increase in maternal mortality ratio per unit time period was about $2 \%$ in Namibia, $9 \%$ in Botswana and 12\% in Lesotho, South Africa and Swaziland. In view of these trends, it is unlikely that any of the southern African countries would achieve the MDG target as the estimated maternal mortality ratios in 2015 for each country surpasses the 2015 target.

Goal 6 deals with HIV/AIDS, malaria and other diseases and the target is to halt and to begin to reverse the spread of HIV/AIDS by 20I5. The indicator used is the HIV prevalence among pregnant women aged 15-24 years. In this article, however, HIV prevalence among persons aged 15-49 years was used as this group is generally considered sexually active and constitutes a substantial part of the population of working age. Figure I which shows trends in HIV prevalence among persons aged 15-49 suggests that Botswana and Namibia have halted and begun to reverse the spread of HIV. South Africa, Lesotho and Swaziland appear to have only stabilized but have not reversed its spread.

\section{Figure I: Trend in HIV prevalence among persons aged I5-49 in Southern Africa}

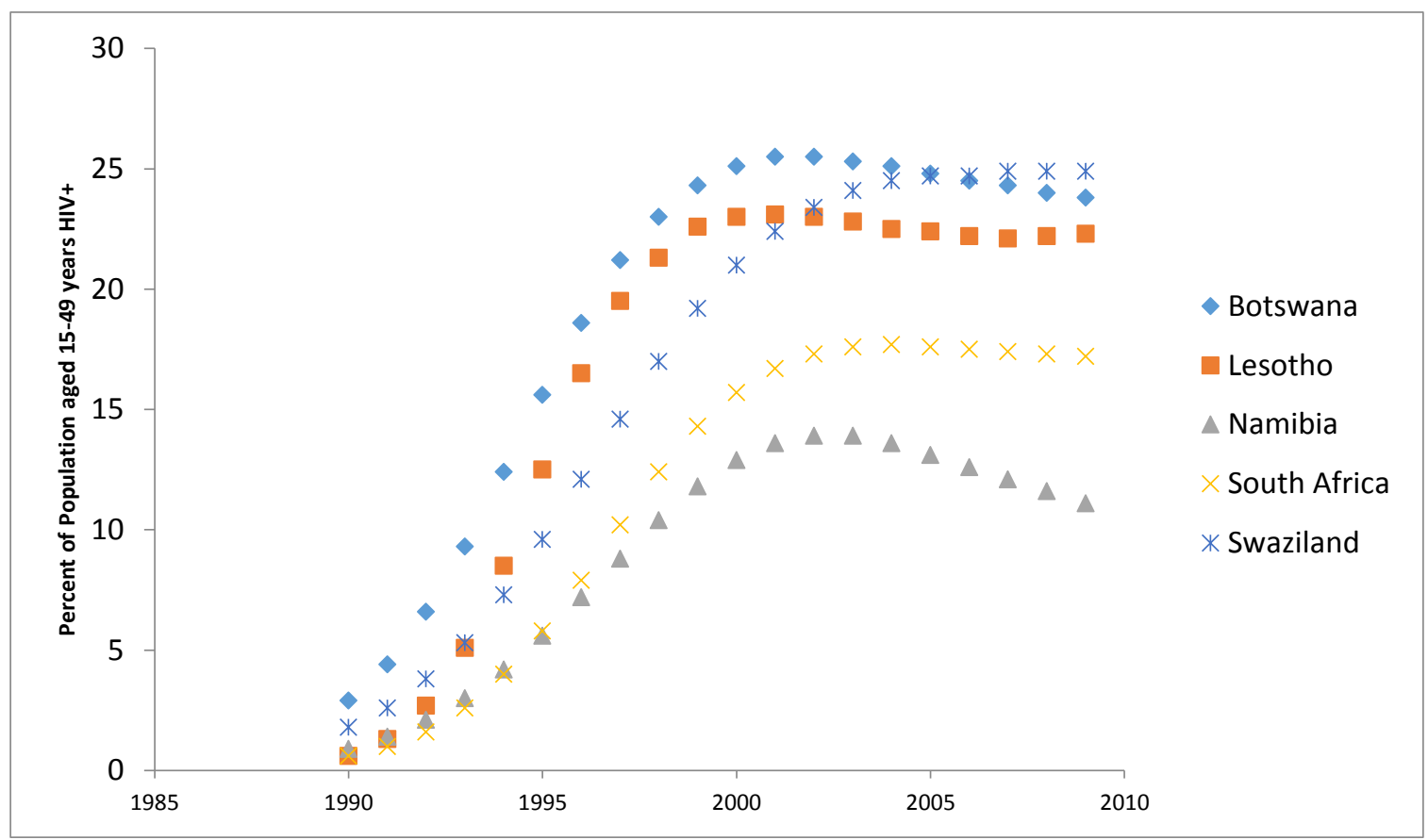

Source: UN database 2012.

\section{Discussion and Conclusion}

This study focused on progress in achieving six MDG targets for Southern Africa with each country's progress being analyzed separately. An overall summary of the results in Table 6 below suggests that of the six MDG goals examined, none of the Southern
African countries is poised to achieve all six goals. At best, Botswana and Swaziland are poised to achieve three of the six MDG goals. At the other extreme end, South Africa is not poised to achieve any of the six MDG goals. 
Table 6: Overall summary of MDG targets achievement in Southern Africa

\begin{tabular}{|l|l|l|l|l|l|}
\hline Targets and indicators & Botswana & Lesotho & Namibia & $\begin{array}{l}\text { South } \\
\text { Africa }\end{array}$ & Swaziland \\
\hline Target I: Population less than I \$ a day & - & Unlikely & - & Unlikely & Likely \\
\hline $\begin{array}{l}\text { Target 3: All children complete primary } \\
\text { schooling }\end{array}$ & Likely & Unlikely & Unlikely & Unlikely & Likely \\
\hline $\begin{array}{l}\text { Target 4: Gender disparity in primary } \\
\text { school enrolment }\end{array}$ & Likely & Likely & Unlikely & Unlikely & Likely \\
\hline Target 5: Reduce under-five mortality & Unlikely & Unlikely & Likely & Unlikely & Unlikely \\
\hline Target 6: Improve maternal health & Unlikely & Unlikely & Unlikely & Unlikely & Unlikely \\
\hline $\begin{array}{l}\text { Target 7: Halt and reverse the spread of } \\
\text { HIV/AIDS }\end{array}$ & Likely & Unlikely & Likely & Unlikely & Unlikely \\
\hline
\end{tabular}

Source: Authors' estimates.

The discrepancies in country performance with regards to targets cannot be disentangled from each country's level of socio-economic development, the challenges faced by vulnerable countries as is the case with African countries, least developed countries, landlocked countries, small island countries and those experiencing conflict, the socio-cultural environments in countries, as well as the capacity constraints that countries encounter (Clemens et al. 2007; UN 20I4). Clemens \& Moss (2005) point out that the nonachievement of the MDGS by the developing countries and African countries cannot be blamed on inertia on the part of governments in African countries, or inefficacy in using aid or shortfalls in aid from donors. In the final analysis the MDGs no doubt would have bettered the lives of some of the poorest which in part is due to positive impact of aid. Thus they argue that non-achievement of the MDGs should not negate the important role that aid plays. The MDGs will remain a contentious issue for years to come but they will form an indelible part of any redress process on development initiatives in the future. In this regard, it has been suggested that "future goals should be built on a shared vision of development and not on the bundling together of a set of independent development targets" (Waage et al.20l0:2).

\section{References}

Center for International Governance (CIGI) and Korean Development Institute (KDI). 2012. Post2015 Development Agenda: Goals, targets and indicators. Special Report. CIGI. www.cigionline.org [accessed 29.1.2014].

Clemens, M.A. and Moss, T.J. 2005. What's wrong with the Millennium Development Goals. CGD Brief, Center for Global Development. Available at http:// www.cgdev.org (accessed 2 July 20I2).

Clemens, M.A, Kenny, C. J and Moss, T.J. 2007. The Trouble with the MDGs: Confronting expectations of Aid and development Success, World Development,35(5):735-75I.

Government of Botswana \& United nations. 2010. Botswana millennium development goals: status report 2010. Gaborone: Ministry of Finance.

Government of the Kingdom of Lesotho. 2014. Millennium development goals: status report 2013. Maseru: Government of the Kingdom of Lesotho.

Government of the Republic of Namibia. 2013. Namibia 2013 millennium development goals: Interim progress report no 4 . Windhoek: National Planning Commission.

Government of Swaziland. 2012. Swaziland millennium development goals progress report 2012. Mbabane: Ministry of Economic Planning.

Hailu, D., and Tsukada, R. 20II. Achieving the Millennium Development Goals: a measure of progress. UNDP Working Paper no 78, Brazil: UNDP.

Hogan, M.C., Foreman, K.J., Naghavi, M., Ahn, S.Y., Wang, M., Makela, S. M., Lopez, A.D., Lozano, R. and Murray, J.L. 2010. "Maternal mortality for $18 \mathrm{I}$ countries, 1980-2008: a systematic analysis of progress towards Millennium Development Goal 5," The Lancet, 375, (9726): 1609-1623.

OECD. 1998. Core set of indicators of development progress. DCD/DAC(98)6.

OECD. 2000. Indicators for the international development goals: a suggestion for some qualitative indicators. $\mathrm{DCD}(2000) 7$.

Republic of South Africa. 2013. Millennium development goals: country report 2013. Pretoria: Republic of South Africa.

Udjo, E. O., Simelane S., and Booysen, D. (2000a). Socio-economic indicators of development progress within the OECD framework in South Africa. Paper presented at the Millennium Conference of Commonwealth Statisticians, Gaborone, Botswana, I-5 May. 
Udjo, E. O., Orkin M., and Simelane S. (2000b). Levels of social indicators in South Africa in relation to international goals of development. Paper presented at the Forum 2000 Seminar on Statistics for Social Progress, Geneva, Switzerland, 27 June.

Udjo E.O. \& Lalthapersad-Pillay, P. 2014. Estimating maternal mortality and causes in South Africa: national and provincial levels, Midwifery, 30: 512518.

United Nations. 2003. Indicators for monitoring the Millennium Development Goals: Definitions, Rationale, Concepts and Sources. New York: UN.

United Nations. 2008. The Millennium Development Report 2008. New York: UN.

United Nations. 2010. The Millennium Development Goals Report 2010. New York: United Nations.

United Nations. 2012. 'Millennium Development Goals Indicators'.

UN.

http://mdgs.un.org/unsd/mdg/Data.aspx. (accessed I2 March 20I2).

United Nations. 2014. The road to dignity: Ending poverty, transforming all lives and protecting the planet. Synthesis Report of the Secretary-General on the Post-2015 Agenda. New York: United Nations.
United Nations Children's Fund (UNICEF). 2008. The Millennium Development Goals Report. New York: United Nations Children's Fund.

United Nations Development Programme (UNDP). 2003. Millennium Development Goals: a compact among nations to end poverty. England: Oxford University Press.

Waage, J., Banerji, R., Campbell, O., Chirwa, E., Collender,G., Dieltiens,V., Dorword, A., GodfreyFaussett, P., Hanvoravongchai, P., Kingdon, G., Little, A., Mills, A., Mulholland, K., Mwinga, A., North, A., Patcharanarumol, W., Poulton, C., Tangcharoensathien, V. \& Unterhalter, E. 2010. 'The Millennium Development Goals: A crosssectoral analysis and principles for goal setting after 2015. Lancet \& the London International Development Centre Commission. Available at http://www.thelancet.com (assessed I3 August 20II).

Williams, T., and Smith, K. B. 2000. "Statistics to shape the $21^{\text {st }}$ Century: the role of indicators." Paper presented at The Conference of Commonwealth Statisticians, Gaborone, I- 5 May.

World Bank and IMF. 20I0. Global Monitoring Report 2010 - The MDGs after the Crisis. Washington: The World Bank. 